\title{
WHY IS IT REASONABLE TO INVEST IN RENEWABLE ENERGY IN UKRAINE?
}

\author{
Yuliia BASHYNSKA ${ }^{1}$, \\ Institute of Regional Researchers of National Academy of Sciences of Ukraine, Ukraine
}

\begin{abstract}
The purpose of the paper is to present the current status of renewable energy development in Ukraine and to highlight the main advantages of investing in renewables in Ukraine. The purpose is also to reveal the biggest renewable energy installations in Ukraine. The paper displays the main financial initiatives of several international organizations and world economic leaders that have already announced plans to aid Ukraine's transition to renewable energy. Methology. The survey is based on an analysis of the natural potential, legislative frameworks of the industry and active financial programmes. Results of the survey provide the most attractive opportunities for investing in the emerging market of renewable energy in Ukraine. The survey also shows the amount of economically viable potential of different renewable energy sources. Besides, it is expected that renewable energy will enhance energy security and reduce the negative impact of industry on the environment. Practical implications. Since 2009 when the green tariff was first introduced in Ukraine, the renewable energy sector has been developed to a great extent. Although the sector faced some policy challenges in 2015 , such as the imposition of new taxes, but technologies experienced rapid growth. Nowadays the use of renewable energy sources is a priority way of sustainable energy system building in Ukraine. There are several state and regional financial initiatives promoting renewable energy sources. As policymakers have focused on the renewable energy development, new investment centered in energy efficiency technologies. There will be a big step in the direction of renewables usage in private housing complexes. Due to the survey, the main problem of renewable energy development is lack of funding. All the efforts made by the government create an enabling environment for foreign direct investments in renewable energy in Ukraine. Value/originality. Wide renewable energy use would be a good solution for Ukraine to decrease the amount of imported energy resources. Boosting of renewable energy will also help to tackle global warming and negative changes of climate. That is why promoting of renewables use is very important for Ukraine. On the other hand, renewable energy can become a profitable business for investors.
\end{abstract}

Key words: renewable energy, investments, energy efficiency, capacity, development, project.

JEL Classification: E 22, O38, Q01

\section{Introduction}

"By supporting Ukraine, you support a new future for Europe and the entire free world.

By supporting Ukraine, you support a nation that has chosen freedom in the most cynical of times" Petro Poroshenko, the president of Ukraine, the Joint Session of the United States Congress, September 2014.

One of the main problems with the current Ukrainian energy sector is low energy efficiency and too much consumption of natural gas, oil, and coal. Due to recent advances in technology there are several excellent alternatives to traditional energy sources such as gas, coal and oil. These alternatives are renewable energy sources and they are available in nearly every country in the world, as the sun shines and wind blows everywhere. Today's economic climate and pressing environmental issues make it ever more crucial to promote sustainable development in order to save our planet's natural resources for future generations.

I believe that renewable energy sources are the best all around solution for enriching Ukraine's industrial, agricultural and residential sectors. Based on the successful implementation of renewable energy throughout the European Union, Ukraine is advantageously positioned to become a highly energy effective and independent state. Ukraine has long been a key energy partner on the continent and already possesses renewable energy infrastructure and rich natural resources that, properly tapped, will greatly reduce dependence of Ukraine on fossil fuel imports from Russia. The current Ukrainian government has already identified renewable energy as a

Corresponding author

${ }^{1}$ Department of Environmental Policy and Natural Resources,

Institute of Regional Researchers of National Academy of Sciences of Ukraine.

E-mail: yu.bashynska@ukr.net 
very high priority for securing independence from Russian gas and oil imports in the near future.

With the adoption of Directive 2009/28/EC Ukraine committed to a binding $11 \%$ target of energy from renewables in gross final energy consumption in 2020, up from $5,5 \%$ in 2009 , and $10 \%$ in the transport sector. A major expansion in renewable electricity generation is planned, in particular from wind, but also from solar photovoltaic, biomass, and large-scale hydro. Renewable sources (bioethanol) goal for the transport sector was listed as a voluntary 5\% share of the total fuel volume in 2013. This amount then became a mandatory $5 \%$ in 2014 , though Ukraine did not manage to meet its target of 5\% for 2014 (Shevchuk and Malysheva, 2014).

There is a very ambitious plan of action to increase energy efficiency already underway that calls for the reduction of energy intensity by $20 \%$ until 2015 , as compared to 2008 , which is very difficult to achieve, given the present constraints in legal and financial support.

The second, possibly even more crucial reason for promoting renewables in Ukraine is ecological. To a large extent, leaders in business and government share consensus that investing in renewable energy is the most desirable way to promote sustainable development. The traditional methods for generating electricity currently in use produce heavy pollutants and continue to cause negative outcomes linked to diseases, structural damage, biosphere disruption, and species degradation.

\section{The Gas Factor}

In Ukraine the single most factor driving the development of renewables is the desire for more autonomy in economic relations with Russia. Ukraine has remained dependent on Russian gas, oil, petroleum and nuclear fuel since gaining independence in 1991. Throughout the decade immediately following independence many domestic and foreign policy decisions were tied to speculations on the price of natural gas in particular. In the present situation, in which relations between Ukraine and Russia are extremely tense, Ukraine's security and autonomy relies on reaching energy independence. The only alternative would be for Russia to continue to set inflated gas price increases, a trend that has adversely affected both Ukraine and Europe in the past. In 2014 Ukraine is slated to import highly over-priced gas ( $\$ 485$ per 1 thousand $\mathrm{m} 3$ ). Although Russia is continuing to sell gas to Europe at a lower rate, the majority of this gas and other fuel products sold to European clients transits through Ukrainian territory. It should be mentioned that in 2013 Ukraine imported nearly 26 billion $\mathrm{m} 3$ of gas from Russia. The price of this gas, which was not economically justified, was a heavy burden for the Ukrainian budget.

The Ukrainian government is considering a multiple options plan for replacing Russian gas, as the 2015-2016 heating season will be a big challenge for the country. Unfortunately, Russian Gazprom has proven that it is an unreliable and unpredictable partner to Ukraine. That's why every effort needs to be made to diversify the energy sector of Ukraine and to safeguard the country against inevitable future breakdowns in relations with Gazprom.

Wide renewable energy use would be a good solution for Ukraine to decrease the amount of imported energy resources. According to the Energy Industry Research Center, Ukraine's heating supply accounts for about 40 percent of all gas imported from Russia, which could be replaced with renewable energy within three to five years. By 2030, renewables could account for about 15 percent of Ukraine's electricity supply, up from about 2 percent now, with adequate investment (Wingfield, 2014).

The Ukrainian government is encouraging the renewable energy sector to achieve four important nationwide aims: to improve energy security, to reduce the dependence on fossil fuels imports, to boost clean energy generation, and to and lower greenhouse gas emissions. In order to support these four priority areas, the state provides guarantees to all investors involved in renewable energy projects. According to the Law on State Guarantees to Promote the Use of Renewable Energy Sources, which was adopted in June 2011, Ukraine guarantees that all electricity produced from renewables will be purchased at the established green tariff for the duration of the green tariff application. The green tariff rate is established individually for each business entity and each renewable energy source until 2030.

\section{Projected Growth}

Many positive steps forward in renewable energy development are already taking place. Several international organizations and world economic leaders have already announced plans to aid Ukraine's transition to renewable energy. The U.S. Agency for International Development (USAID) recently launched a program that aims to help 17 Ukrainian cities conduct energy reform and improve energy efficiency, with emphasis on developing a renewable energy sector. USAID has promised US \$13.5 million towards the program (Vorotnikov, 2014).

The logic follows that with the rapid growth of industry and population, Ukraine will need more electricity and heat production. It is more efficient to cover the deficit of energy that will occur in the future with renewable energy sources than with traditional energy. Achieving this aim for Ukraine is not easy because of many factors. The main reason is the lack of funding for renewable energy development. The current political infrastructural changes and budgetary constraints in Ukraine pose specific challenges to immediate state investments in the construction of renewable energy objects. Thus, Ukraine must attract more foreign investment in renewable energy projects.

During last few years, Ukraine has developed renewable energy more intensively than traditional, enhancing energy security and reducing the negative impact of industry on the environment. Following the results of 2011-2013, more solar and wind power plants were installed than coal and gas power plants, both in number and by installed capacity. In 2013 the total new renewables capacity reached 535.5 
MW. During the period of 2011-2012 more than two 2 billion Euros were invested in the renewable energy sector.

According to EBRD, Ukraine may soon become a key leader among environmentally friendly economies in Europe with its renewable energy sector being among the most prospective and attractive for investments. The forecast is that investments in Ukrainian renewable energy generation, including solar and wind energy, biomass and biofuel production, could reach nearly 5 billion USD in the next 5 years (Yevtushenko, Vakht. 2012).

\section{Areas of Investment: Hydro, Wind, Solar, Biomass}

For 2014 EBRD has prolonged financing energy efficient projects in Ukraine, launching a new financial programme of 100 million Euro to develop sustainable energy sources and to promote energy efficiency in Ukraine. Having invested 2.8 billion USD into renewable energy projects, Ukraine has outstripped several other developing countries, even those with slightly higher economic rakings: Turkey, Thailand, Morocco, Argentina, Mexico and all countries of Latin America excluding Brazil. According to UNEP data, Ukraine was among ten dominant countries of the world in asset finance* of renewable energy assets in 2012. Investments in renewable energy rose from 919 million USD in 2011 to 2.8 billion in 2012 , which is equal to $205 \%$ of growth. The advance was driven by the financing of a series of small hydro projects totaling $980 \mathrm{MW}$ and worth 2.1 billion in the Dnipro river. The largest project in another sector was that for the 90MW, 126 million Botievo Wind farm (phase 1) on the cost of the Azov sea in Zaporizhia region (Global trends in renewable energy investment, 2013) ${ }^{1}$.

In 2013 Wind Power LLC signed a loan agreement in the amount of 138 million Euro for the second phase of the Botievo Wind farm. The construction is expected to be complete by the end of 2014. The loan was granted by the LandesBank Berlin (LBB), one of the largest banks in Germany. The loan has a tenure of 10 years and will be used for financing the second stage of the Botievo wind farm, which includes thirty five Vestas wind turbines V112-3,0 MW with total capacity of $105 \mathrm{MW}$. The total investments in Botievo wind farm are valued at 340 million Euro. Despite the difficult political and economic situation in Ukraine, Wind Power LLC is not going to stop constructing wind farms in Ukraine. The company is planning to build 2 new wind farms with a total capacity of $350 \mathrm{MW}$ in the south of the country.

Wind energy is being developed in Ukraine at a fast pace. During 2013 alone 95.3 MW of new wind energy capacity was put into operation. Thus, on the 31 st of December 2013 the total installed capacity of wind energy sector in Ukraine amounted to 371.2 MW compared with 276 MW in 2012, which corresponds to the rate of growth of the industry at a level of $56 \%$. The amount of electricity generated form wind reached 633 million $\mathrm{kWh}$ which is equivalent to $0.33 \%$ of total electricity generation in Ukraine.

In general, at the end of 2013 the total capacity of mounted wind turbines in the country amounted to 472.9 MW, and 101.7 MW of them are currently under connection to the grid. Furthermore, many projects of wind power plants construction were started in Lugansk, Kherson regions and in Crimea. In 2013, all wind farms of Ukraine produced more than 630 million $\mathrm{kWh}$ of electricity, accounting for $0.33 \%$ of total electricity production in the country. Thanks to "green" electricity produced by wind energy, $\mathrm{CO} 2$ emissions have been reduced by 512000 tones. The leading wind power companies in Ukraine are "Wind Parks of Ukraine" LTD and "Wind Power " LTD DTEK (UWEA, 2014).

In terms of the entire territory of Ukraine it's not a powerful achievement, but it's only the beginning of wind energy development in the country and we hope it will continue.

A significant growth was seen also in solar energy. In 2012 the installed capacity of solar energy accounted to $372 \mathrm{MW}$ which is $95,8 \%$ more than in 2011 . The share of solar energy in all renewables capacity was $6 \%$ and $0.7 \%$ of all electricity generation. Due to the forecast made by the company Energici Holdings Inc, in 2017 the total installed solar capacity in Ukraine will amount to $3087 \mathrm{MW}$. Ukraine took the 22nd place in the world in comparison with the other solar markets. The legislation is also attractive with stimulus and policies in 5 categories out of 14 .

At various stages of implementation there have been more than 100 projects of solar power plants construction with a total capacity of over $1380 \mathrm{MW}$. Most of the objects are built by foreign companies from Portugal, Germany, France, Austria, Czech Republic, Israel and some Ukrainian developers.

Due to Hans-Josef Fell, who framed the German renewable energy legislation, Ukraine can produce enough biogas even to export it to Europe instead of Russian natural gas. The main reason that hampered the development of electricity generation from biogas in Ukraine was the absence of "green tariff" for biogas until April 2013. Due to the new legislation, the companies that produce electricity from biogas or biomass can claim to sell it to the national energy market at the price of 0.1 Euro/Kwh (the rate of "green tariff" for March 2014). Nowadays there are only five companies generating electricity from biomass and four entities using biogas which work on "green tariff" in Ukraine. Besides, according to the review of the energy sector of Ukraine prepared by the International Energy Agency, Ukraine should develop a new energy strategy that will allow it

\footnotetext{
${ }^{1}$ All money invested in renewable energy generation projects (excluding large hydro), whether from internal company balance sheets, from loans, or from equity capital. This excludes Refinancings.
} 
to make full use of the country's potential for renewable energy development, particularly biogas and municipal waste for heat and power generation.

Before the political crisis, Ukrainian solar energy was rated as the most attractive for investing among Eurasian countries and took 29th position at the world list. After a positive change of government and the election of a new president, there is now an even stronger political will in Ukraine to attract the funds to support an even wider range of renewables.

\section{Current Initiatives}

Thanks to a joint investment by EBRD and EIG Engineering a first biomass heat power plant was constructed in the Kyiv region with a capacity of $6 \mathrm{MW}$. Total planned capacity of the plant is $18 \mathrm{MW}$ and it will help Ukraine to save 40 million cubic meters of natural gas annually. For now the plant works in a test regime. The option of using biofuel (wood, straw and other waste of agricultural plants) is especially attractive and economically sound for villages and towns with no more than 20,000 residents and they happen to account for nearly half of the country's population.

In today's difficult economic climate most Ukrainians cannot afford to buy PV systems, wind turbines or biogas machines because they are too expensive. That's why small utility-scale projects are not widespread in Ukraine. Most of the realized projects are of large capacity. But thanks to global trends, solar and wind systems prices have fallen. For Ukraine the sharply reduced cost of solar PV systems is a good sign. It means that a greater amount of PV capacity can be installed at a lower cost. The Ukrainian renewable energy market is very attractive for foreign investors now because it is just being developed.

Additionally, over a 5-year period to the first quarter of 2014 the worldwide average cost of electricity has declined by $53 \%$ for crystalline silicon PV systems, and $15 \%$ for onshore wind turbines. Over the same timeframe, the cost per MWh of coal- and gas-fired generation has increased in many countries, including Ukraine (Global Trends in Renewable Energy Investment, 2014).

Energy-smart technologies is a brand new branch of industry for Ukraine that is just now entering a rapid stage of development. The rich prospects to be found in ecologically-friendly production may soon also lead to establishing an energy-efficient car industry within the country. Ukraine is in the process of designing a scientific research test center for safe, environmentally-friendly and energy-efficient vehicles that will involve a new state-ofthe-art complex of laboratories with high-tech equipment.

\section{The Five Main Reasons to Invest:}

1) Ukraine possesses a very rich natural potential of all renewable energy sources:

- The country's wind technical potential is one of the highest among CIS countries (around 5,000 MW). According to the Wind Energy Association, wind energy potential in Ukraine is estimated at $30000 \mathrm{GWh}$. Ukraine is in top-four European countries, most suitable for generating electricity from wind. The greatest wind energy potential is located in the vast areas adjacent to the Black Sea and the Azov Sea, as well as the Carpathian Mountains, Transcarpathian and Lower Carpathian areas. Ukraine's renewable energy sector currently produces power at a much lower cost than other countries. For instance, producing one MWh of wind energy costs roughly USD 33,1 compared with USD 145 in the Czech Republic, and USD 50 in China in terms of 2012 (Ervin and O'Sullivan, 2012).

Ukraine has an impressive potential of biomass available for energy generation. According to the Ministry of Agrarian policy of Ukraine, potential of biodiesel production is estimated at $1 \mathrm{mln}$ tons/year and nstitutio production $-2 \mathrm{mln}$ tons/year. Biomass technical potential is high: nearly $50 \mathrm{TWh}$. Biomass energy production can be based on agricultural and forestry waste. Annual economic potential of crop waste expected to be equivalent to 14 million tons of coal. The full annual biomass resources available in Ukraine are equal to 70 million tons per year. To use it it's possible to create a network of stations with the total capacity of $7000 \mathrm{MW}$. Moreover, biomass energy development in Ukraine is the most cost-effective due to the presence of stable raw material during the day and night and all seasons, as opposed to more expensive and cyclic solar energy and wind.

- According to the Ukrainian Agricultural Confederation, burning even a half of the straw and corn stalks left on the fields can produce the energy equivalent of 11-13 bn $\mathrm{m} 3$ of natural gas.

- Average solar technical potential is close to $4 \mathrm{kWh} / \mathrm{m} 2 /$ day.

The potential of solar energy in Ukraine is high enough for a wide introduction of the heat energy and PV equipment almost on the entire territory. Use of the available technical potential can allow saving nstitu. $5 \mathrm{bln}$. M3 of natural gas. An average annual amount of the total solar radiation which accesses $1 \mathrm{~km} 2$ of the surface on the territory of Ukraine is within $1070 \mathrm{kWh} / \mathrm{m} 2$ in the northern part of Ukraine up to $1400 \mathrm{kWh} / \mathrm{m} 2$ inn the south of Ukraine and higher in the AR Crimea. The period of effective operation of the helioenergy equipment in the southern regions of Ukraine is 7 months (from April to October), in the northern regions - 5 months (May to September - data of UNIDO, GEF). By comparison, the amount of solar energy reaching the earth's surface in Ukraine in terms of 1 sq.m is higher than in Germany which has been the world's top PV installer for several years.

- Technically feasible hydro power potential of small rivers of Ukraine amounts to about 8.4 billion kWh or about $4,5 \%$ of total electricity consumption in 2010. Majority of hydro power plants need modernization. According to the Ukrainian legislation, small hydro power plants are those electric power stations with installed generation capacity not exceeding $10 \mathrm{MW}$. Western region of Ukraine has the 
biggest potential for development of small hydro power stations, but it requires some investments in this sector (Ervin and O'Sullivan, 2012).

- Hydroenergy has been historically strong, but technology needs upgrading. Ukraine's 22400 rivers are a significant source of renewable energy capacity in the form of hydroelectric potential. However, because only 110 of these rivers are broader and longer than $100 \mathrm{~km}$, future hydroelectric growth will come from small hydroelectric installations. The Ministry of Energy and Coal Industry provides estimating that hydroelectric capacity could reach $5.8 \mathrm{GW}$ by 2030 . And according to data provided by the Renewable Energy Institute of the National Academy of Science of Ukraine, the hydroenergy potential could even reach 12.5 GW (Ukraine Alternative energy sector outlook, 2011).

2) In Ukraine there is an enabling legislation to support the renewables sphere. The main advantage is high "green tariffs" and exemption from some tax and customs duties. Tax exemptions are granted to: enterprises selling energysaving equipment of their own production (on $80 \%$ of income) and enterprises implementing energy-saving projects (on $50 \%$ of income). Enterprises generating electricity from renewable energy sources and biofuel producers are exempt from income taxes until 2020, inclusive. No customs duties or VAT are leveraged on equipment imported for renewable energy production. Additionally, the state energy market is obligated to purchase all electricity generated from renewable energy sources.

3) The Ukrainian renewable energy market is not widely advertised and promoted abroad. For this reason levels of foreign investment and competition have so far remained low, but are expected to grow exponentially. The share of renewables in total energy supply is still very low (below $3 \%$ ) but the number of companies engaged in this sector is increasing.

4) Ukraine has a developed scientific and technical base for renewable energy development. In addition, the country has developed the production of modern high-tech equipment for the "green" energy during the last three years.

Ukraine is one of Europe's largest producers of solar panels and components to them, though they are often more expensive than imported equipment. Ukrainians also have their own research and development achievements in this area. Recently, the American Journal of R\&D Magazine has ranked among the best world scientific developments the autonomous energy supply system, invented by scientists of the National University "Lviv Polytechnic".

This device can charge household appliances, mobile phones and illuminate a small room. The system that catches stray light, can, for example, be sewed to a bag or a tourist tent.

Another Ukrainian inventors led by the chief designer doctor Olexiy Onipko developed a wind turbine that can generate electricity at a low wind speed. The successfully designed rotor installation is driven even when the wind speed is of $0.1 \mathrm{~m}$ per second. This device can be used almost on the entire territory of Ukraine. The advantage is that the turbine operates in a wide range of wind speeds up to $20 \mathrm{~m} / \mathrm{s}$. So at a speed of $15 \mathrm{~m} / \mathrm{s}$ its efficiency is equivalent to the classical powerful wind plant. The invention won the "Green Oscar" in the global competition as the best invention in the field of renewable energy in 2013.

5) Active national programs and international organizations' support for renewable energy projects.

- European Union: budget support to the implementation of the energy strategy in the field of energy efficiency and renewable energy, capacity building on domestic solar heating, hot water and insulation for rural and remote areas, implementation of energy efficiency measures in several cities, etc.;

- The Ukraine Sustainable Energy Lending Facility (USELF) is an investment facility of up to $€ 50$ million established by the European Bank for Reconstruction and Development (EBRD) for fostering renewable energy projects in Ukraine;

- National project "Energy of nature” (pre-feasibility studies, partner search and investment support): construction of wind farms (EUR 40 million for a 10 MW plant) and solar power plants (EUR 150 million for a 100 MW plant), with an IRR of $15-20 \%$ and a payback period of 5-7 years (data of State Agency for Investments and National projects of Ukraine) ;

- National project "Biomass energy" (pre-feasibility studies, partner search and investment support): construction of co-generation plants using biomass in Kyiv and other industrial cities and operation during more than 25 years (investment up to EUR 7 million) with an IRR of more than $25 \%$ and a payback period of 5 years;

- The Green for Growth Fund Southeast Europe (GGF) provides Megabank, Ukraine with a credit line for financing energy efficiency (EE) and renewable energy (RE) investments to Ukrainian Micro, SME and Corporate clients. Through its Technical Assistance Facility (TAF) Megabank is supported with a technical assistance component for development of EE strategy and loan products with the final goal of institutionalizing the EE lending into the bank's structure.

According to the The Brattle Group/SEIA report the energy independence provides great energy and economic security. Germany would have been in a much more difficult situation with the recent crisis in Ukraine if it were not for the country's strong renewable energy market. But this sort of energy independence is important all around the world, especially if we take into account oil and the potential to electrify our ground transport. As the recent Ukraine crisis has shown, the transition has also helped reduce the exposure of Germany to potentially volatile input prices to the traditional power system, a benefit that has largely remained unquantified, but could prove significant in the future (Shanan, 2014). 


\section{Conclusions}

For Ukraine it is very important to develop renewable energy because of the critical dependency on imports of fossil fuels and tough ecological problems within the country, but also throughout Europe. The main obstacle to wide renewable energy sources use is the lack of funding. Because of the budget deficit, the state cannot afford enough financing to fully transition to a renewable energy sector at the present time. However, recent changes make investment in Ukrainian renewables highly favorable. The current government is encouraging private entities to invest in the renewable energy sector by providing enabling legislation and beneficial economic initiatives such as a "green tariff".
Thus, it is economically beneficial not only for Ukraine, but also for the E.U. and U.S. to invest in Ukrainian renewable energy development, because the U.S. and E.U. cannot solve global warming on their own. Moreover, since Ukraine borders the E.U. directly, sustainable ecological conditions in Ukraine will also have a positive impact on its neighboring countries. Ukraine is the largest country by landmass in Europe and possesses a great renewables potential, tech capital, human resources, and geostrategic position between Europe and Russia.

Now is a prime time for foreign investors to capture an emerging market. Investments in Ukraine's low-carbon future need to be made now. Given the recent positive political changes in Ukraine, there is a determined political will and support to attract investments in this new and exciting sector.

\section{References}

Brian Wingfield (2014, April, 29). Ukraine Seeks Renewable Energy Investors to Loosen Russia's Grip. Renewable energy world. Retrieved from: http://www.renewableenergyworld.com/rea/news/article/2014/04/ukraineseeks-renewable-energy-investors-to-loosen-russias-grip?cmpid=BioNL-Tuesday-April29-2014

Carolyn Ervin, Anthony O’Sullivan, Elena Miteva, Attracting investments in renewable energy in Ukraine. Private sector development Policy handbook. OECD. Nov. 2012, p. 16.

FS-UNEP Collaborating Centre, Global Trends in Renewable Energy Investment 2014, p. 16. Retrieved from: http://fs-unep-centre.org/publications/gtr-2014

Vladislav Vorotnikov (2014, April, 22 ), Renewable Energy May Help Ukraine Abandon Russian Gas. Renewable energy world. Retrieved from: http://www.renewableenergyworld.com/rea/news/article/2014/04/renewableenergy-may-help-ukraine-abandon-russian-gas?cmpid=SolarNL-Tuesday-April22-2014

Press release of the Ukrainian Wind Energy Association (UWEA), 2014. Ukrainian Wind Market in 2013. Retrieved from: http://www.uwea.com.ua/news.php?news_id=183\&lng=ENG

Sergiy Yevtushenko, Vladimir Vakht. (2012). Renewable energy in Ukraine, industry overview. Retrieved from: http://investukraine.com/wp-content/uploads/2012/06/Renewable-energy-in-Ukraine_230_230_WWW.pdf State Agency for Investments and National projects of Ukraine, National project Energy of nature. Presentation available at: http://www.ukrproject.gov.ua/en/project/energy-nature

Shevchuk, V., Malysheva, N., Kovalchuk. The policy of energy-efficient development and climate change. Monograph / V. Shevchuk. - K.: CP “Comprint”, 2014. - 64 p.

United Nations Environment Programme (UNEP) and Bloomberg New Energy Finance, Global trends in renewable energy investment, 2013, p. 25. Retrieved from: www.unep.org/pdf/GTR-UNEP-FS-BNEF2.pdf

UNIDO, GEF.Available potential of solar energy development in Ukraine. Retrieved from: http://www.reee.org.ua/ en/renewable-energy/solar/

Zachary Shanan (2014, August, 8), German solar feed tariffs wildly successful. RenewEconomy. Retrieved from: http://reneweconomy.com.au/2014/german-solar-feed-tariffs-wildly-successful-63851

\section{Юлия БАШИНСКАЯ}

\section{ПОЧЕМУ СТОИТ ИНВЕСТИРОВАТЬ В ВОЗОБНОВЛЯЕМУЮ ЭНЕРГЕТИКУ В УКРАИНЕ?}

Аннотация. Целью работы является представление текущего состояния развития возобновляемых источников энергии в Украине и выделение основных преимуществ инвестирования в возобновляемые энергетику в Украине. Целью также является показать самые большие установки возобновляемых источников энергии в Украине. Статья отображает основные финансовые инициативы ряда международных организаций и мировых экономических лидеров, которые уже объявили о планах, чтобы помочь переходу Украины на возобновляемые источники энергии. Методика. Исследование основано на анализе природного потенциала, законодательной базы отрасли и действующих финансовых программ. Результаты исследования дают наиболее привлекательные возможности для инвестирования в развивающийся рынок возобновляемых источников энергии в Украине. Исследование также показывает количество экономически жизнеспособного потенциала различных возобновляемых источников энергии. Кроме того, ожидается, что возобновляемые источники энергии будут способствовать укреплению энергетической безопасности и снижению негативного воздействия промышленности на окружающую среду. Практическое значение. С 2009 года, когда зеленый тариф 
Vol. 1, 2015

был впервые введён в Украине, сектор возобновляемых источников энергии в значительной степени развит. Хотя сектор столкнулся с некоторыми проблемами смены политики в 2015 году, например, введение новых налогов, но для технологий ВИЭ наблюдается быстрый рост. В настоящее время использование возобновляемых источников энергии является приоритетным путём построения устойчивой энергетической системы в Украине. Есть несколько государственных и региональных финансовых инициатив, способствующих использованию возобновляемых источников энергии. Как только политики сосредоточились на развитии возобновляемых источников энергии, новые инвестиции последовали в энергоэффективные технологий. Ожидается будет большой спрос в направлении ВИЭ в частных жилых комплексах. В следствие исследования, главная проблема развития возобновляемых источников энергии является недофинансирование. Все усилия правительства сейчас направлены создать благоприятную среду для прямых иностранных инвестиций в возобновляемые источники энергии в Украине. Значение/оригинальность. Широкое использование возобновляемых источников энергии будет хорошим решением для Украины, чтобы уменьшить количество импортируемых энергоресурсов. Повышение уровня использования возобновляемых источников энергии также будет способствовать решению глобального потепления и негативных изменений климата. Именно поэтому продвижение использования возобновляемых источников энергии очень важно для Украины. С другой стороны, возобновляемая энергетика может стать прибыльным бизнесом для инвесторов. 